\title{
Shellfish Allergy: Unmet Needs in Diagnosis and Treatment
}

\author{
Gelis $\mathrm{S}^{1}$, Rueda $\mathrm{M}^{2}$, Valero $\mathrm{A}^{1}$, Fernández $\mathrm{EA}^{3}$, Moran $\mathrm{M}^{3}$, Fernández-Caldas $\mathrm{E}^{3,4}$ \\ 'Department of Pneumology and Allergy, Hospital Clinic, Institut d'Investigacions Biomèdiques August Pi i Sunyer (IDIBAPS), Barcelona, Spain \\ ${ }^{2}$ Allergology Department, Hospital Quirónsalud, Barcelona, Spain \\ ${ }^{3}$ Inmunotek SL, Madrid, Spain \\ ${ }^{4}$ University of South Florida College of Medicine, Tampa, Florida, USA
}

J Investig Allergol Clin Immunol 2020; Vol. 30(6): 409-420

doi: 10.18176/jiaci.0565

\section{Abstract}

Seafood is a major cause of food allergy and anaphylaxis worldwide. Shellfish is included among the "big eight" food groups, which are responsible for more than $90 \%$ of all cases of food allergy. Approximately $2.5 \%$ of the world's population has experienced an adverse reaction to seafood. Seafood allergy is one of the most frequent and lethal allergies that exist.

The several allergenic proteins involved in allergic reactions that have been described in recent years include tropomyosin, arginine kinase, myosin light chain, and sarcoplasmic calcium-binding protein. Despite all the data reported in the last few years, shellfish allergy is still diagnosed and treated as it was 50 years ago. The only effective treatment to prevent allergic reactions to shellfish is avoidance. This review aims to update recently published data on shellfish allergy and to highlight those areas that have yet to be resolved.

Key words: Shellfish. Shrimp. Allergy. Allergens. Diagnosis. Food allergy.

\section{Resumen}

La alergia al marisco es una causa importante de alergia alimentaria y anafilaxia en todo el mundo. Los mariscos se incluyen entre los "ocho grandes" grupos de alimentos, responsables de más del $90 \%$ de todos los casos de alergia alimentaria. Aproximadamente el 2,5\% de la población mundial ha experimentado alguna reacción adversa a los mariscos. La alergia al marisco es una de las alergias más frecuentes y letales que existen.

Se han descrito varias proteínas alergénicas involucradas en las reacciones alérgicas en los últimos años: tropomiosina, arginina quinasa, cadena ligera de la miosina, proteína de unión a calcio, entre otras. A pesar de la información obtenida en los últimos años, la alergia a los mariscos todavía se diagnostica y trata como hace 50 años. Actualmente, el único tratamiento efectivo para prevenir reacciones alérgicas a los mariscos es la evitación.

Esta revisión tiene como objetivo recoger todas las actualizaciones realizadas en las publicaciones de los últimos años y resaltar las cuestiones pendientes de resolver.

Palabras clave: Marisco. Gamba. Alergia. Alérgenos. Diagnóstico. Alergia a alimentos. 


\section{Introduction}

Seafood is a major cause of food allergy and anaphylaxis worldwide. The terms seafood and shellfish are often used interchangeably, yet their meaning is different. Seafood refers to several distinct groups of edible aquatic animals including fish, crustaceans, and mollusks, whereas shellfish refers only to crustaceans and mollusks.

Shellfish is one of the "big eight" food groups that are responsible for more than $90 \%$ of all cases of food allergy. Approximately $2.5 \%$ of the world's population has experienced an adverse reaction to seafood [1]. The prevalence of shellfish allergy varies from $0 \%$ to $10.3 \%$ depending on the geographical area studied and is generally higher in regions where seafood is frequently consumed $[2,3]$.

In Spain, shellfish is the third cause of food allergy in adults, behind fruit and nuts [4]. In children, the prevalence is lower than in adults.

Shellfish is defined as any edible marine invertebrate. Crustaceans belong to the phylum Arthropoda and are taxonomically classified alongside insects and arachnids [5]. The phylum includes prawn, crab, and lobster species, all of which may contain species-specific as well as common allergenic proteins, which are known as pan-allergens. These molecules have a high sequence homology, which favors crossreactivity with other crustaceans and between crustaceans and other arthropods such as dust mites or cockroaches.

Mollusks belong to the phylum Mollusca [5] and are divided into bivalves (clams, scallops, cockles, mussels, oysters), gastropods (snail, abalone, limpet), and cephalopods (squid, octopus). The probability of cross-reactivity between these mollusks is not well established, and few proteins seem to be shared by crustaceans and mollusks. The shared proteins that have been described have a low amino acid sequence homology and are therefore less likely to cross-react.

For many years, tropomyosin has been thought to be the most important allergen in shellfish. However, in the last 15 years, several studies have shown the complexity and the variability of the allergenic composition of this food group. Today, there is clear evidence that several proteins are involved in the allergenicity and cross-reactivity of shellfish.

Within the shellfish family, the better studied group are the crustaceans. Most studies have been conducted with shrimp.

\section{Shellfish Allergens}

Shellfish allergens comprise a large and increasingly growing list of allergens that covers various species. The most important are presented in Table 1 .

\subsection{Tropomyosin}

A $38-\mathrm{kDa}$ thermostable protein identified in 1981 seemed to be responsible for shrimp allergy [6]. In the following years, several authors reported that patients with symptoms of immediate hypersensitivity after ingesting prawns had a positive skin prick test (SPT) result and circulating specific IgE to crustaceans $[7,8]$. Tropomyosin, the first allergen described in seafood, was identified in Penaeus indicus (Pen i 1), commonly known as Indian white prawn, in 1993 [9]. This panallergen is involved in invertebrate muscle contraction [10] and is considered one of the most important pan-allergens within allergens of animal origin [11]. Tropomyosin has been described in numerous invertebrate species; in addition to crustaceans, it has also been identified in mollusks, cockroach, nematodes such as Anisakis simplex, and dust mite [12-17]. Tropomyosin has also been described in vertebrates, although it is not allergenic $[18,19]$.

Tropomyosin has been considered the most important allergen of shrimp for many years. Several studies show that in $72 \%-98 \%$ of patients sensitized to shrimp, IgE binds to the purified allergen [20-22], although a recent Italian multicenter study found that less than $50 \%$ of sensitized patients recognize it [23].

Shrimp tropomyosin, prawn tropomyosin, lobster tropomyosin, and crab tropomyosin share a sequence identity of $91 \%-100 \%$. The sequence identity between crustacean and mollusk tropomyosin is lower, approximately $65 \%$ [11].

The tropomyosin of invertebrates is thermostable and resistant to digestion [24-27].

\subsection{Arginine Kinase}

Arginine kinase (AK) was the second shellfish allergen identified, in 2008. It was first identified in Penaeus monodon (Pen m 2) [28], commonly known as black tiger shrimp, and subsequently in many other crustaceans [29,30], such as crab [31], octopus [32], cockroach [33], and dust mite $[34,35]$. AK is more unstable and less resistant than tropomyosin $[24,36]$. Since it is thermolabile and volatile, it is considered one of the allergens responsible for respiratory symptoms induced by steam inhalation $[37,38]$.

The percentage of patients sensitized to prawn who recognize $\mathrm{AK}$ is not well defined, although it is thought to range between $10 \%$ and $51 \%$ [22,39].

\subsection{Myosin Light Chain}

The third shellfish allergen described, in 2008, was myosin light chain (MLC). MLC was identified in American white shrimp, Litopenaeus vannamei (Lit v 3) [40], and later in other shrimp species, lobster [41], crab [42], and cockroach [20].

Like tropomyosin, it is highly resistant [24] and is considered a minor allergen, with a frequency of sensitization ranging from $19 \%$ to $55 \%[43,44]$, depending on the series. Although it usually accompanies tropomyosin in sensitization, there have been reports in patients with allergy due to shrimp intake, including anaphylaxis, in whom MLC was the only responsible allergen $[39,40]$.

\subsection{Sarcoplasmic Calcium-binding Protein}

Described in 2008, immediately after Lit v 3, sarcoplasmic calcium-binding protein (SCP), was located first in Penaeus monodon (Pen $\mathrm{m}$ 4) [44]. It is highly resistant and stable [45] and has high sequence homology with crustaceans but low homology with mollusks $[46,47]$. As in the case of MLC, it is a minor allergen that could be clinically relevant regardless of sensitization to tropomyosin [39]. It is common in children, in whom the frequency of sensitization reaches $85 \%[46,22]$. 
Table 1. Description of Shellfish Allergens

\begin{tabular}{|c|c|c|c|c|c|}
\hline Component & $\begin{array}{l}\text { Allergen } \\
\text { Described }\end{array}$ & $\begin{array}{l}\text { Route of } \\
\text { Exposure }\end{array}$ & $\begin{array}{l}\text { Molecular } \\
\text { Weight }\end{array}$ & Resistance & $\begin{array}{l}\text { Available for } \\
\text { Diagnosis }\end{array}$ \\
\hline Tropomyosin & $\begin{array}{l}\text { Pen a } 1 \\
\text { Lit v } 1 \\
\text { Pen m } 1 \\
\text { Cra c } 1 \\
\text { Mel } 11 \\
\text { Pan b } 1 \\
\text { Pen i } 1 \\
\text { Met e } 1 \\
\text { Por p } 1 \\
\text { Hom a } 1 \\
\text { Scy o } 1 \\
\text { Scy p 1 } \\
\text { Scy s } 1 \\
\text { Cha f } 1\end{array}$ & $\begin{array}{l}\text { Ingestion } \\
\text { Inhalation }\end{array}$ & $34-38 \mathrm{kDa}$ & $\begin{array}{l}\text { Highly thermostable } \\
\text { and IgE-reactive }\end{array}$ & $\begin{array}{l}\text { rPen a } 1^{\text {a }} \\
\text { nPen } m 1^{b}\end{array}$ \\
\hline Arginine kinase & $\begin{array}{l}\text { Pen a } 2 \\
\text { Pen m } 2 \\
\text { Cra c } 2 \\
\text { Lit v } 2 \\
\text { Scy o } 2 \\
\text { Scy p } 2 \\
\text { Scy s } 2 \\
\text { Cha f } 2 \\
\text { Met e } 2 \\
\text { Por p } 2\end{array}$ & $\begin{array}{l}\text { Ingestion } \\
\text { Inhalation }\end{array}$ & $40-45 \mathrm{kDa}$ & $\begin{array}{l}\text { Labile } \\
\text { Can elicit } \\
\text { IgE binding }\end{array}$ & nPen $m 2^{b}$ \\
\hline Myosin light chain & $\begin{array}{l}\text { Pen m } 3 \\
\text { Lit v } 3 \\
\text { Cra c } 3 \\
\text { Hom a } 3\end{array}$ & Ingestion & $17-20 \mathrm{kDa}$ & Stable & \\
\hline $\begin{array}{l}\text { Sarcoplasmic } \\
\text { calcium-binding protein }\end{array}$ & $\begin{array}{l}\text { Pen m } 4 \\
\text { Lit v } 4 \\
\text { Cra c } 4 \\
\text { Mel } 14 \\
\text { Pon } 14 \\
\text { Scy p } 4 \\
\text { Cha f } 4 \\
\text { Met e } 4 \\
\text { Por p } 4\end{array}$ & Ingestion & $20-25 \mathrm{kDa}$ & Stable & nPen $\mathrm{m} 4^{\mathrm{b}}$ \\
\hline Troponin C & $\begin{array}{l}\text { Lit v } 6 \\
\text { Cra c } 6 \\
\text { Hom a } 6 \\
\text { Pen m } 6 \\
\text { Scy o } 6 \\
\text { Pan b } 6\end{array}$ & Ingestion & $20-21 \mathrm{kDa}$ & Unknown & \\
\hline $\begin{array}{l}\text { Triose phosphate } \\
\text { isomerase }\end{array}$ & $\begin{array}{l}\text { Pen m } 8 \\
\text { Cra c } 8 \\
\text { Arc s } 8 \\
\text { Pro c } 8 \\
\text { Scy p } 8\end{array}$ & $\begin{array}{l}\text { Ingestion } \\
\text { Inhalation }\end{array}$ & $26-29 \mathrm{kDa}$ & Labile & \\
\hline Hemocyanin & $\begin{array}{l}\text { Lit v Hemocyanin } \\
\text { Pan b Hemocyanin } \\
\text { Mac r Hemocyanin }\end{array}$ & Ingestion & $72-75 \mathrm{kDa}$ & Stable & \\
\hline Paramyosin & $\begin{array}{l}\text { Myt g PM } \\
\text { Oct v PM }\end{array}$ & & $100 \mathrm{kDa}$ & & \\
\hline $\begin{array}{l}\text { Fructose } 1,6 \\
\text { Biphosphate aldolase }\end{array}$ & & $\begin{array}{l}\text { Ingestion } \\
\text { Inhalation }\end{array}$ & $39-43$ & Labile & \\
\hline
\end{tabular}

Abbreviations: Cha f, Charybdis feriata (crucifix crab); Cra c, Crangon crangon (common shrimp); Lit v, Litopenaeus vannamei (pacific white shrimp); Mac r, Macrobrachium roserbergii (giant freshwater prawn); Mel I, Melicertus latisulcatus (king prawn); Met e, Metapenaeus ensis (sand shrimp); Mit g, Mytilus galloprovincialis (black mussel); Oct v, Octopus vulgaris (common octopus); Pan b, Panadalus borealis (red shrimp); Pen a, Penaeus aztecus (brown shrimp); Pen i, Penaeus indicus (Indian white prawn); Pen $\mathrm{m}$, Penaeus monodon (black tiger shrimp); Pon I, Pontastacus leptodactulus (narrow clawed crayfish); Por p, Portunus pelagicus (blue swimmer crab); Pro c, Procambarus clarkia (red swamp crawfish); Scy o, Scylla olivacea (mud crab); Scy p, Scylla paramamosain (green mud crab); Scy s, Scylla serrata (mangrove crab). aRecombinant allergens: originally identified in native allergenic extracts and obtained by molecular biology techniques.

${ }^{b}$ Native allergens: obtained from the allergenic source. 


\subsection{Other Allergens}

Other allergens reported during the last 15 years include troponin C $[20,43,37,48-50]$, triose phosphate isomerase $[20,22,51,52]$, hemocyanin [39,53-56], fructose biphosphate aldolase [34], fatty acid-binding protein, $\alpha$-actinin and $\beta$-actinin [57,34], ubiquitin [34], paramyosin [58], and myosin heavy chain [54]. The clinical relevance of these allergens remains to be determined.

It is worth mentioning that hemocyanin, with unclear relevance in shellfish allergy, seems to have a very important role in cross-reactivity with mite, cockroach, and other invertebrates such as snails [59].

\subsection{Epitopes}

The study of peptides using microarray techniques has enabled us to identify linear peptides involved in sensitization to allergens. The epitopes described to date include 8 epitopes of tropomyosin [22,60-62], 7 epitopes of AK, 5 epitopes of MLC, and 3 epitopes of SCP [43].

Sensitization to various epitopes may account for the crossreactivity between invertebrates and the variety of symptoms that patients experience $[22,43,62]$.

\section{Cross-reactivity Syndromes}

\subsection{Involvement of Tropomyosin}

As previously mentioned, cross-reactivity between crustaceans, between crustaceans and mollusks, and between crustaceans and mollusks and mites or cockroaches, is mainly due to the high sequence identity of tropomyosin between the different species.

Cross-reactivity is attributed to the epitope that the patient recognizes. The 8 tropomyosin epitopes reported to date are epitopes 1, 2, 3a, 3b, 4, 5a, 5b, and 5c. In-depth analysis of these epitopes suggested that they can be classified into 3 groups. The first, comprising the 5a epitope, is highly conserved among crustaceans, mollusks, insects, and mites. The second, which comprises epitopes 2,3 , and 4 , is found in arthropods but not in mollusks. And the third, which comprises epitopes 1, 5b, and $5 \mathrm{c}$, seems to be specific to crustaceans [61-63].

Sensitization to tropomyosin can occur through the digestive route by consumption of shellish or through the respiratory tract by inhalation of mites or by inhalation of shellfish vapors. Some studies have shown that sensitization to shellfish can trigger dust mite sensitization and vice versa. It seems that the prevalence of shrimp allergy is higher in regions with a high prevalence of house dust mite (HDM) allergy. In fact, in these regions, a positive SPT result is found in almost all patients sensitized to shrimp, and this may or may not be clinically relevant. Approximately $30 \%$ of HDM-allergic patients are sensitized to Der $p 10$ [64].

Wong et al [65] reviewed the evidence supporting the hypothesis that inhaled HDM tropomyosin is the main sensitizer for shellfish allergy in hot and humid tropical climates. A study conducted in the United States by Wang et al [66] showed a positive significant correlation between high specific IgE levels to shrimps and high exposure to cockroach allergens in urban children. Yang et al [67] obtained similar results in rural patients in southern China. Furthermore, Fernandes et al [68] reported a series of Orthodox Jews who presented sensitization to shrimp without ever being exposed to them. Thus, it seems that sensitization to shellfish may be explained by the presence of mites or cockroaches in the environment and the consequent sensitization to these arthropods. Conversely, there seem to be shellfish-allergic patients with positive SPT or specific IgE results against mite or cockroach without having had contact with these allergenic sources, although this finding is less frequent [34].

\subsection{Involvement of Other Allergens}

Allergens other than tropomyosin could explain crossreactivity between dust mite and shrimp.

The proteins AK $[28,34,69]$, SCBP $[22,44,70]$, and hemocyanin $[39,70]$ may also be involved in this crossreactivity syndrome.

Yang et al [67] reported that in some cases of shrimp sensitization due to cross-reactivity with cockroaches, tropomyosin was not the dominant allergen responsible for the cross-reactivity.

Asero et al [23] conducted a multicenter study that included 116 Italian shrimp-allergic adults. Only $40 \%$ were positive to tropomyosin. In $52 \%$, specific IgE binding to the $>60-\mathrm{kDa}$ component was detected.

Giuffrida et al [39] conducted a study to determine the clinical relevance of hemocyanin in patients allergic to shrimp and postulated that this allergen is a possible marker of crossreactivity with mites.

Kamath et al [70] studied the importance of hemocyanin as an allergen in children, as well as its cross-reactivity with HDM.

Although sequence identity between shellfish hemocyanin and HDM hemocyanin has been demonstrated, Piboonpocanun et al [53] reported selective allergy to the giant freshwater shrimp Macrobrachium rosenbergii by exclusive sensitization to hemocyanin in patients tolerating Penaeus monodon [53].

More recently, Gámez et al [34] postulated that $\alpha$-actinin and ubiquitin could be implicated in shrimp-mite crossreactivity. Finally, according to Kamath et al [70], enolase could be a major allergen that explains cross-reactivity in infants.

\subsection{Cross-reactivity Between Crustaceans and Mollusks}

Although cross-reactivity between HDM and crustaceans is well documented, few studies have analyzed cross-reactivity between crustaceans and mollusks.

Vidal et al [71] recruited patients with anaphylaxis to crustaceans and noted that mollusk-allergic patients had higher levels of specific IgE to tropomyosin ( $\mathrm{rPen}$ a 1 ) and more intense specific IgE binding in immunoblots to the shrimp extract. No differences were found between groups regarding AK, MLC, SCP, troponin C, and $\alpha / \beta$ actin [71].

No other trials have demonstrated the usefulness of biomarkers (level of IgE to prawn or tropomyosin, sensitization to specific allergens) to predict the likelihood of crossreactivity between crustaceans and mollusks. Epitope mapping 
of the allergens seems to provide useful information (see above) $[43,62]$.

\subsection{Sensitization to Shellfish Induced by Allergen Immunotherapy}

For many years, there has been an ongoing discussion about the possibility of inducing allergy to shellfish in previously tolerant patients receiving specific HDM immunotherapy. Several cases of patients who developed a new allergy have been reported [72]. Likewise, tolerance to seafood after HDM immunotherapy has been described in allergic patients who had previously presented severe allergy and even episodes of anaphylaxis $[73,74]$. Both reactions, the new induced shrimp allergy and the apparent desensitization to shrimp, have been reported for subcutaneous immunotherapy and for sublingual immunotherapy.

It is still unknown why food allergy improves in some patients, yet develops in others. Prospective studies suggest that it may depend on the level of tropomyosin in the immunotherapy extracts, but this level has not been identified $[75,76]$. The role of tropomyosin in HDM and shellfish allergies constitutes an important field of research, as it can provide new insights and strategies into immunotherapy for treatment of shellfish allergy [65].

\section{Clinical Manifestations}

There is no pathognomonic symptom of shellfish allergy. The clinical manifestations associated with an allergic reaction after the ingestion of shellfish are the same as those observed after ingestion of other foods.

The clinical manifestations may appear as oral allergy syndrome (OAS) or affect the skin in the form of rash, urticaria, or angioedema. They may involve the gastrointestinal, respiratory, or cardiovascular systems.

As in most food allergies, reactions begin immediately, in the first 15 or 20 minutes after intake. IgE-mediated allergic reactions are considered to occur within the first 2 hours, although there are always exceptions. The same is true of shellfish [77]. Late phase reactions have been reported from 2 to 8 hours after ingestion of shrimp, limpet, snow crab, and abalone [77-79].

Some studies suggest that shellfish is one of the foods most frequently involved in allergic reactions and that it can cause more severe reactions.

Alergológica 2015, an epidemiologic study based on the Spanish population, revealed that clinical presentations took the form of skin involvement in $72.9 \%$ of cases, OAS in $31.3 \%$, digestive symptoms in $10.4 \%$, asthma in $4.2 \%$, rhinitis in $2.1 \%$, and anaphylaxis in $12.5 \%$ [4]. A similar study conducted in Australia showed that patients experienced contact urticaria in $15 \%$ and anaphylaxis in $21 \%$ [80]. A review conducted in Hong Kong showed a high percentage of skin involvement (95.7\%), followed by respiratory symptoms (29.9\%), gastrointestinal symptoms $(16.3 \%)$, cardiovascular symptoms $(3.3 \%)$, and anaphylaxis $(11.9 \%)$ [81,82].

In addition to the classic symptoms caused by the ingestion of a food, other symptoms have been reported for shellfish contact and steam inhalation. Exposure during processing in factories and in the home may cause other allergic symptoms, such as contact urticaria $[83,84]$, contact dermatitis, and respiratory symptoms [85]. In the respiratory tract, the symptoms may result from the inhalation of the vapor/smell of the shellfish itself or from inhalation of steam during the cooking process.

There seems to be a strong correlation between a high concentration of allergens in the air and increased allergic sensitization [86]. Asthma induced by steam inhalation in fishermen and shellfish workers and in seafood industry processing factories is considered occupational asthma $[38,85,87,88]$.

\subsection{The Role of Cofactors}

Physical exercise, nonsteroidal anti-inflammatory drugs, and alcohol consumption are enhancers of allergic reactions due to food intake [89-91]. The role of cofactors in shellfish allergy is not well established. Some cases of anaphylaxis after ingestion of shellfish followed by exercise have been reported [92-94]

Other factors that can increase the likelihood of an allergic reaction include stress, sleep deprivation, concomitant diseases, acute infections, and menstruation $[89,95]$.

\section{Diagnosis}

As in all food allergies, the diagnosis of shellfish allergy is based mainly on the clinical history. After an exhaustive interview, additional tests are used to confirm the suspected diagnosis. These include SPTs, specific serum IgE determinations, and oral food challenge (OFC).

The first step is to perform SPT with one of the commercially available extracts. This procedure is safe and rapid, although it has been reported to be unreliable. Asero et al [96] analyzed 5 commercial crustacean extracts using SDS-PAGE and compared them with a fresh prawn extract. The authors found that the commercial extracts contained fewer protein bands than the fresh prawns and that molecular weight bands corresponding to the major shrimp allergens were lacking.

In a similar study conducted several years earlier by Jirapongsananuruk et al [82], 68 children diagnosed with prawn allergy underwent SPT with a commercially available extract and prick-prick testing with fresh and raw prawns. The authors demonstrated that crude extracts are useful when screening for sensitization to shrimp and better than commercial extracts.

Carnés et al [97] evaluated how the cooking process may alter the in vivo and in vitro allergenicity of the shrimp and lobster extracts and showed that more patients could be identified using boiled extracts of shrimp and American and spiny lobsters than using raw extracts. Additionally, wheal diameters and specific IgE levels were also significantly higher using boiled extracts. Jirapongsananuruk et al [82] found similar results (see above); therefore, the use of boiled extracts seems to be more effective in diagnosing seafood allergy. However, since some studies showed contradictory 
results concerning the effect of heat on these extracts $[24,98]$, a negative SPT result could be a false negative. If real allergy is suspected, it is necessary to perform a prick-prick test with the food — both raw and cooked — to confirm sensitization [99].

In vitro diagnostic methods could also prove useful. The data provided during determination of specific $\operatorname{IgE}$ to the whole extract is similar to that of the SPT. The presence of specific IgE in serum implies sensitization but does not correlate with symptoms and/or severity [100].

Neither the size of the wheal nor the IgE level makes it possible to distinguish sensitized from allergic patients.

At present, OFC is the only test capable of differentiating an asymptomatic sensitized individual from an allergic patient. Double-blind placebo-controlled food challenge (DBPCFC) is considered the gold standard for diagnosis of food allergy [101], and several protocols have been proposed. Jirapongsananuruk et al [82] followed a 3-step protocol with 15-minute intervals between doses, starting with $500 \mathrm{mg}$ of shrimp and reaching a cumulative dose of $15.5 \mathrm{~g}$. Nordlee et al [102] conducted the DBPCFC with shrimp incorporated into a seasoned ground cooked beef matrix. Seven doses ranging from $7 \mu \mathrm{g}$ to $4 \mathrm{~g}$ of shrimp were administered, and placebo was interspersed between the doses. While there is currently no standardized initial dose for the OFC, the European Academy of Allergy and Clinical Immunology recommends an initial dose of $5 \mathrm{mg}$ of shrimp, increasing every 15-30 minutes until the daily recommended dose for the patient's age is reached [101]. These tests are not exempt from risk, and many can induce serious anaphylactic reactions $[82,101,102]$.
The introduction of molecular diagnostic techniques during the last 20 years [103] has opened a new field in the study of allergy. In addition to revealing the complete allergenic source, molecular techniques make it possible to study the allergens individually. Applying single allergenic molecules from shellfish for allergen-specific IgE detection (ie, risk-associated molecules, markers of primary species, and indicators of cross-reactivity) could potentially modify test sensitivity and analytical specificity [104].

Component-resolved diagnosis and epitope mapping have been applied to a wide range of allergens to elucidate distinct sensitization profiles, which more accurately reflect clinical reactivity, and thus obviate, in some cases, the need to perform an OFC [105].

For some foods, such as peanut [106,107], milk [108,109], and egg [110], a positive connection has been found between the recognition of certain sequential IgE binding epitopes and the degree of allergic reactivity. It has been suggested that patients with persistent allergy or a history of more severe reactions recognize a larger number of sequential $\operatorname{IgE}$ epitopes. In addition, some pan-allergens have been correlated with greater or less severity.

Allergy to apple provides an example of the different manifestations of allergy symptoms regarding sensitization to different allergens from the same source. While sensitization to Mal d 4 (profilin) is associated with OAS, sensitization to Mal d 3 (lipid transfer protein) is associated with a risk of anaphylactic reactions after intake of apple.

In shellfish allergy, the significance of allergens is not clear. Patients with persistent allergy or a history of more severe

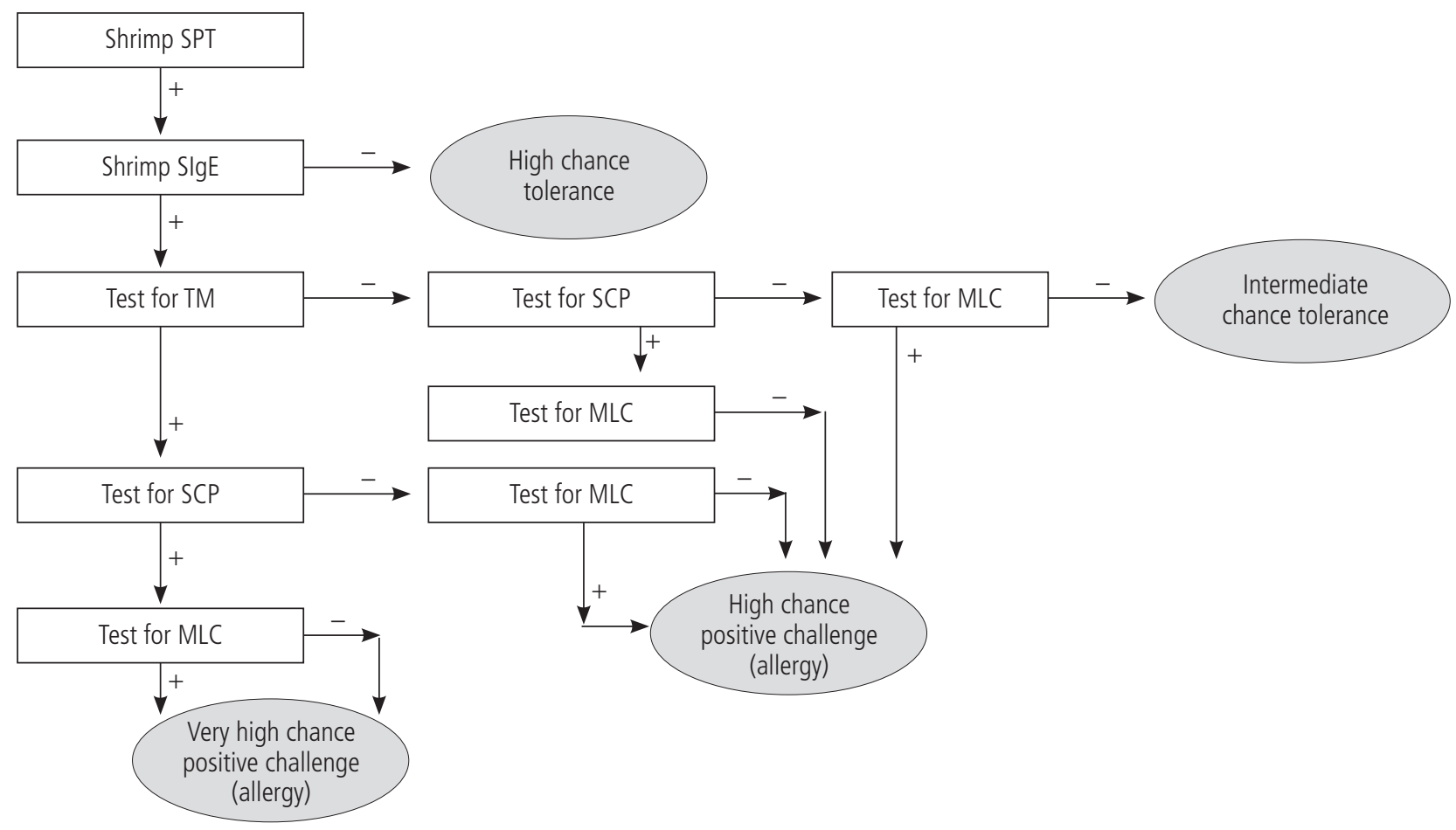

Figure. Flow diagram showing a protocol for diagnosis of shrimp allergy, as suggested by Pascal et al [43] in 2015. MLC indicates myosin light chain; SCP, sarcoplasmic calcium-binding chain; SPT, skin prick test; TM, tropomyosin. 
reactions recognize many sequential IgE epitopes [67]. In addition, recognition of epitopes and allergens differs between children and adults [22]. According to the study conducted by Ayuso et al [22], 94\% of children recognized tropomyosin, $70 \%$ MLC, $67 \% \mathrm{AK}$, and 59\% SCP. In adults, tropomyosin was detected in $61 \%$, MLC in $31 \%$, AK in $21 \%$, and SCP in $21 \%$. Tropomyosin was the most frequently recognized allergen in both groups of patients. The other allergens were predominantly recognized by children. This might suggest that tropomyosin could be associated with the persistence of shrimp allergy into adulthood. However, as mentioned above, tropomyosin is a pan-allergen that cross-reacts with other common allergens, such as mite and cockroach. Therefore, the presence of crustacean tropomyosin may be due to crossreactive sensitization, with no clinical relevance.

Determination of specific IgE against tropomyosin is the most specific protein-based approach and seems to have a higher positive predictive value in the case of oral provocation [111]. In addition to tropomyosin, SCP may be clinically relevant in children $[39,44]$.

Pascal et al [43] conducted a study with the aim of identifying allergens and epitopes associated with clinical reactivity to shrimp. Patients with positive DBPCFC results recognized tropomyosin alone or in combination with $\mathrm{SCP}$ and/or MLC. AK and hemocyanin were recognized by patients with positive SPT results to HDM or cockroach and shrimp who never developed symptoms after ingestion of crustaceans. The authors believed that AK and hemocyanin could indicate cross-reactivity between shrimp and arthropods, albeit with no clinical significance. Based on results from 86 patients, the authors proposed a protocol to diagnose allergic patients based on a diagram that takes into consideration the outcome of SCP, specific IgE, and positive results for tropomyosin, SCP, and MLC (Figure).

The allergens currently marketed for in vitro diagnosis of crustaceans are nPen $\mathrm{m} 1$ and rPen a 1 (both tropomyosin), nPen $\mathrm{m} 2$ (AK), and nPen $\mathrm{m} 4$ (SCP) (ImmunoCAP ISAC multiple 112 p, Thermo Fisher Scientific) and nPen m 1 (ALEX multiplex allergy test, MADX).

Finally, as in other conditions, knowing the genetic alterations that are associated with different types of allergy could facilitate diagnosis and treatment. Unfortunately, this type of study is still at a very immature stage in the allergy field. Several genome-wide association studies focused on samples from patients of European ancestry have identified food allergy-specific loci in the HLA class II region. Khor et al [112] conducted a study using data from 11011 Japanese allergic women and identified shrimp allergy-and peach allergy-specific loci in the HLA-DR/DQ region, suggesting that allergy to certain foods may be related to genetic differences that tag both HLA alleles, with particular epitope-binding specificities, as well as variants modulating the expression of specific HLA genes.

\section{Treatment}

The only effective prophylaxis for allergic reactions to shellfish is avoidance [113].

Allergen-specific immunotherapy is proving successful in the treatment of patients with allergy to milk, egg, peanut, and wheat $[114,115]$. To our knowledge, none of the active groups studying shellfish allergy have conducted studies with oral immunotherapy.

The cross-reactivity of tropomyosins in arthropods and the clinical contribution of the other shellfish allergens hamper accurate diagnosis and design of allergen immunotherapy for shellfish allergy [116].

\section{Discussion and Unmet Needs}

Studying shellfish allergy is not an easy task. In addition, given that it is one of the most frequent and lethal allergies, we tend to advise avoidance in patients who have presented compatible symptoms, whether by intake, inhalation, or contact.

In the case of patients with suspected seafood allergy whose SPT result and specific IgE serum determination are negative, OFC (simple or DBPCFC) should be performed to demonstrate tolerance, although some OFC results may prove to be positive [117].

When sensitization is confirmed by positive SPT or by specific IgE, the same OFC should be performed as in the previous case, although very often it is not performed, sometimes because of patient refusal and sometimes because the physician does not wish the patient to undergo a risky procedure. Finally, challenge may not be possible owing to

Table 2. Research Needs in Shellfish Allergy

1. Determine the type of commercial extract with more sensitivity for detection of allergic individuals

- Raw extract

- Cooked extract

- Single species

- A mixture of species

2. Look for marks that determine the real probability of cross-reactivity between crustaceans, cephalopods, and bivalves.

3. Assess the possibility of using nasal provocation tests as a diagnostic tool:

- As a previous step in the OFC

- To replace the OFC

- To confirm the diagnosis in patients who have experienced anaphylaxis and in whom OFCs are contraindicated

Determine the type of extract to be used in a nasal provocation:

- Cooked or raw extract

- Single species or a mixture

- The amount of protein to be applied

4. Carry out oral provocation studies with lyophilized extracts of different crustacean species containing all known allergens

5. Determine how individuals who have had an allergic reaction in the presence of a cofactor should be studied

6. Find a marker of mite-shrimp cross-reactivity in HDMallergic patients who are not allergic to shrimp

Abbreviations: HDM, house dust mite; OFC, oral food challenge. 
the lack of resources. It should be borne in mind that OFC requires adequate spaces within a hospital, skilled staff, and a long-term investment. Consequently, food allergy is generally diagnosed without assessment, and in many cases, patients may follow unnecessary avoidance diets.

In cases where the challenge can be performed, treatment is with avoidance diet if the challenge result is positive. Therefore, if the challenge is with shrimp, we must ask whether the avoidance diet should include all shellfish, or only crustaceans, or only shrimp. In addition, the decision to follow an avoidance diet or not may depend on the severity of the reaction or the results of the SPT carried out with other prawns or lobsters. No accurate answers have been proposed for these dilemmas to date.

Another scenario would involve a challenge yielding negative results. We would then have to ask whether patients who experienced a reaction did so in the context of a cofactor or whether the OFC was reliable. Therefore, in such cases, it would be necessary to ask whether patients could eat the foods they wished or only foods without the cofactor and whether tolerance to the crustacean used in the challenge implies tolerance for all crustaceans. Returning to the vegetable model, demonstrating tolerance to apple does not imply being tolerant to peach, even if both share the same pan-allergen.

We urgently require diagnostic tools to reduce the number of patients who avoid shellfish unnecessarily and to prevent fatal reactions in patients who are misdiagnosed (Table 2).

Commercial extracts must be perfected.

It is mandatory to continue working on molecular diagnostics in order to determine the significance of the allergens.

Alternative diagnostic challenges, for example, nasal provocation tests using acoustic rhinometry, should be investigated.

Finally, it is worth mentioning the need to find an option that enables patients to be cured. Maybe knowing the exact significance of each shellfish allergen would enable us to propose oral immunotherapy, as in the case of milk, egg, and peanut.

\section{Funding}

The authors declare that no funding was received for the present study.

\section{Conflicts of Interest}

The authors declare that they have no conflicts of interest.

\section{References}

1. Ruethers $T$, Taki AC, Johnston EB, Nugraha $R$, Le TTK, Kalic T, et al. Seafood allergy: A comprehensive review of fish and shellfish allergens. Mol Immunol. 2018;100:28-57.

2. Nwaru BI, Hickstein L, Panesar SS, Roberts G, Muraro A, Sheikh A, et al. Prevalence of common food allergies in Europe: a systematic review and meta-analysis. Allergy. 2014;69(8):992-1007.

3. Moonesinghe $H$, Mackenzie $H$, Venter $C$, Kilburn S, Turner $P$, Weir $K$, et al. Prevalence of fish and shellfish allergy: A systematic review. Ann Allergy Asthma Immunol. 2016;117(3):264-72.
4. De la Hoz B. Alergia a alimentos. SEAIC. In: Alergológica 2015. 2017:206-27.

5. Catalogue of life. http://www.catalogueoflife.org

6. Hoffman DR, Day ED, Miller JS. The major heat stable allergen of shrimp. Ann Allergy. 1981;47(1):17-22.

7. Waring NP, Daul CB, deShazo RD, McCants ML, Lehrer SB. Hypersensitivity reactions to ingested crustacea: clinical evaluation and diagnostic studies in shrimp-sensitive individuals. J Allergy Clin Immunol. 1985;76(3):440-5.

8. Daul CB, Morgan JE, Waring NP, McCants ML, Hughes J, Lehrer SB. Immunologic evaluation of shrimp-allergic individuals. J Allergy Clin Immunol. 1987;80(5):716-22.

9. Shanti KN, Martin BM, Nagpal S, Metcalfe DD, Rao P. Identification of tropomyosin as the major shrimp allergen and characterization of its IgE-bindind epitopes. J Immunol. 1993; 151(10):5354-63.

10. Daul CB, Slattery $M$, Reese $G$, Lehrer SB. Identification of the major brown shrimp (Penaeus aztecus) allergen as the muscle protein tropomyosin. Int Arch Allergy Immunol. 1994;105(1):49-55.

11. Reese G, Ayuso R, Lehrer SB. Tropomyosin: An invertebrate pan-allergen. Int Arch Allergy Immunol. 1999;119(4):247-58.

12. Leung PSC, Chen YC, Mykles DL, Chow WK, Li CP, Chu $\mathrm{KH}$. Molecular identification of the lobster muscle protein tropomyosin as a seafood allergen. Mol Mar Biol Biotechnol. 1998;7(1):12-20.

13. Yadzir ZHM, Misnan R, Murad S. Identification of tropomyosin as major allergen of white squid (Loligo edulis) by twodimensional immunoblotting and mass spectrometry. Southeast Asian J Trop Med Public Health. 2012;43(1):185-91.

14. Yadzir ZHM, Misnan R, Bakhtiar F, Abdullah N, Murad S. Tropomyosin, the major tropical oyster Crassostrea belcheri allergen and effect of cooking on its allergenicity. Allergy Asthma Clin Immunol. 2015;11:30.

15. Mohamad Yadzir ZH, Misnan R, Bakhtiar F, Abdullah N, Murad S. Tropomyosin and actin identified as major allergens of the carpet clam (Paphia textile) and the effect of cooking on their allergenicity. Biomed Res Int. 2015;2015:254152.

16. Asturias JA, Gómez-Bayón N, Arilla MC, Martínez A, Palacios R, Sánchez-Gascón F, et al. Molecular characterization of American cockroach tropomyosin (Periplaneta americana allergen 7), a cross-reactive allergen. J Immunol. 1999;162(7):4342-8.

17. Arrieta I, Del Barrio M, Vidarte L, Del Pozo V, Pastor C, GonzalezCabrero J, et al. Molecular cloning and characterization of an IgE-reactive protein from Anisakis simplex: Ani s 1. Mol Biochem Parasitol. 2000;107(2):263-8.

18. James JK, Pike DH, Khan IJ, Nanda V. Structural and Dynamic Properties of Allergen and Non-Allergen Forms of Tropomyosin. Structure. 2018;26(7):997-1006

19. Ayuso R, Lehrer SB, Tanaka L, Ibañez MD, Pascual C, Burks $A W$, et al. IgE antibody response to vertebrate meat proteins including tropomyosin. Ann Allergy Asthma Immunol. 1999;83(5):399-405.

20. Bauermeister $K$, Wangorsch A, Garoffo LP, Reuter A, Conti A, Taylor SL, et al. Generation of a comprehensive panel of crustacean allergens from the North Sea Shrimp Crangon crangon. Mol Immunol. 2011;48(15-16):1983-92.

21. Gámez C, Sánchez-García S, Ibáñez MD, López R, Aguado E,

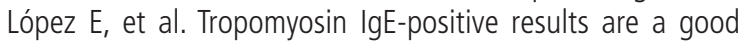
predictor of shrimp allergy. Allergy. 2011;66(10):1375-83. 
22. Ayuso R, Sánchez-Garcia S, Lin J, Fu Z, Ibáñez MD, Carrillo T, et al. Greater epitope recognition of shrimp allergens by children than by adults suggests that shrimp sensitization decreases with age. J Allergy Clin Immunol. 2010;125(6):1286-93.

23. Asero R, Mistrello G, Amato S, Ariano R, Colombo G, Conte $\mathrm{ME}$, et al. Shrimp allergy in Italian adults: A multicenter study showing a high prevalence of sensitivity to novel high molecular weight allergens. Int Arch Allergy Immunol. 2011;157(1):3-10.

24. Kamath SD, Rahman AMA, Voskamp A, Komoda T, Rolland $J M, O^{\prime}$ Hehir RE, et al. Effect of heat processing on antibody reactivity to allergen variants and fragments of black tiger prawn: A comprehensive allergenomic approach. Mol Nutr Food Res. 2014;58(5):1144-55.

25. Kamath SD, Rahman AMA, Komoda T, Lopata AL. Impact of heat processing on the detection of the major shellfish allergen tropomyosin in crustaceans and molluscs using specific monoclonal antibodies. Food Chem. 2013;141(4):4031-9.

26. Liu GM, Huang YY, Cai QF, Weng WY, Su WJ, Cao MJ. Comparative study of in vitro digestibility of major allergen, tropomyosin and other proteins between Grass prawn (Penaeus monodon) and Pacific white shrimp (Litopenaeus vannamei). J Sci Food Agric. 2011;91(1):163-70.

27. Gámez C, Zafra MP, Sanz V, Mazzeo C, Ibáñez MD, Sastre J, et al. Simulated gastrointestinal digestion reduces the allergic reactivity of shrimp extract proteins and tropomyosin. Food Chem. 2015; 173:475-81.

28. Yu C-J, Lin Y-F, Chiang B-L, Chow L-P. Proteomics and Immunological Analysis of a Novel Shrimp Allergen, Pen m 2. J Immunol. 2003;170(1):445-53.

29. Rosmilah M, Shahnaz M, Zailatul HMY, Noormalin A, Normilah I. Identification of tropomyosin and arginine kinase as major allergens of Portunus pelagicus (blue swimming crab). Trop Biomed. 2012;29(3):467-78.

30. García-Orozco KD, Aispuro-Hernández E, Yepiz-Plascencia G, Calderón-de-la-Barca AM, Sotelo-Mundo RR. Molecular characterization of arginine kinase, an allergen from the shrimp Litopenaeus vannamei. Int Arch Allergy Immunol. 2007; 144(1):23-8.

31. Misnan R, Murad S, Yadzir ZHM, Abdullah N. Identification of the major allergens of Charybdis feriatus (red crab) and its cross-reactivity with Portunus pelagicus (blue crab). Asian Pacific J Allergy Immunol. 2012;30(4):285-93.

32. Shen H-W, Cao M-J, Cai Q-F, Ruan M-M, Mao H-Y, Su W-J, et al. Purification, cloning, and immunological characterization of arginine kinase, a novel allergen of Octopus fangsiao. J Agric Food Chem. 2012;60(9):2190-9.

33. Sookrung $N$, Chaicumpa $W$, Tungtrongchitr $A$, Vichyanond $P$, Bunnag C, Ramasoota $P$, et al. Periplaneta americana arginine kinase as a major cockroach allergen among Thai patients with major cockroach allergies. Environ Health Perspect. 2006;114(6):875-80.

34. Gámez C, Zafra MP, Boquete M, Sanz V, Mazzeo C, Ibáñez MD, et al. New shrimp IgE-binding proteins involved in mite-seafood cross-reactivity. Mol Nutr Food Res. 2014;58(9):1915-25.

35. Xing $P, Y u H Q$, Li $M$, Xiao XJ, Jiang $C$, Mo LH, et al. Characterization of arginine kinase, anovel allergen of dermatophagoides farinae (Der $f$ 20). Am J Transl Res. 2015;7(12):2815-23.
36. Chen HL, Mao HY, Cao MJ, Cai QF, Su WJ, Zhang YX, et al. Purification, physicochemical and immunological characterization of arginine kinase, an allergen of crayfish (Procambarus clarkii). Food Chem Toxicol. 2013;62:475-84.

37. Abdel Rahman AM, Kamath SD, Gagné S, Lopata AL, Helleur R. Comprehensive proteomics approach in characterizing and quantifying allergenic proteins from northern shrimp: Toward better occupational asthma prevention. J Proteome Res. 2013;12(2):647-56.

38. Gautrin D, Cartier A, Howse D, Horth-Susin L, Jong M, Swanson $M$, et al. Occupational asthma and allergy in snow crab processing in Newfoundland and Labrador. Occup Environ Med. 2010;67(1):17-23.

39. Giuffrida MG, Villalta D, Mistrello G, Amato S, Asero R. Shrimp allergy beyond tropomyosin in Italy: Clinical relevance of arginine kinase, sarcoplasmic calcium binding protein and hemocyanin. Eur Ann Allergy Clin Immunol. 2014;46(5):1727.

40. Ayuso R, Grishina G, Bardina L, Carrillo T, Blanco C, Ibáñez $M D$, et al. Myosin light chain is a novel shrimp allergen, Lit v 3. J Allergy Clin Immunol. 2008;122(4):795-802.

41. Kim BK, Kim KS, Oh C-W, Mykles DL, Lee SG, Kim HJ, et al. Twelve actin-encoding cDNAs from the American lobster, Homarus americanus: cloning and tissue expression of eight skeletal muscle, one heart, and three cytoplasmic isoforms. Comp Biochem Physiol B Biochem Mol Biol. 2009;153(2):17884.

42. Zhang YX, Chen HL, Maleki SJ, Cao MJ, Zhang LJ, Su WJ, et al. Purification, Characterization, and Analysis of the Allergenic Properties of Myosin Light Chain in Procambarus clarkii. J Agric Food Chem. 2015;63(27):6271-82.

43. Pascal M, Grishina G, Yang AC, Sánchez-García S, Lin J, Towle $D$, et al. Molecular Diagnosis of Shrimp Allergy: Efficiency of Several Allergens to Predict Clinical Reactivity. J Allergy Clin Immunol Pract. 2015;3(4):521-9.

44. Shiomi K, Sato Y, Hamamoto S, Mita H, Shimakura K. Sarcoplasmic calcium-binding protein: Identification as a new allergen of the black tiger shrimp Penaeus monodon. Int Arch Allergy Immunol. 2008;146(2):91-8.

45. Chen HL, Cao MJ, Cai QF, Su WJ, Mao HY, Liu GM. Purification and characterisation of sarcoplasmic calcium-binding protein, a novel allergen of red swamp crayfish (Procambarus clarkii). Food Chem. 2013;139(1-4):213-23.

46. Ayuso R, Grishina G, Ibáñez MD, Blanco C, Carrillo T, Bencharitiwong $R$, et al. Sarcoplasmic calcium-binding protein is an EF-hand-type protein identified as a new shrimp allergen. J Allergy Clin Immunol. 2009;124(1):114-20.

47. Mita H, Koketsu A, Ishizaki S, Shiomi K. Molecular cloning and functional expression of allergenic sarcoplasmic calciumbinding proteins from Penaeus shrimps. J Sci Food Agric. 2013;93(7):1737-42.

48. Chao E, Kim HW, Mykles DL. Cloning and tissue expression of eleven troponin-C isoforms in the American lobster, Homarus americanus. Comp Biochem Physiol - B Biochem Mol Biol. 2010;157(1):88-101.

49. Hindley J, Wünschmann S, Satinover SM, Woodfolk JA, Tim Chew F, Chapman MD, et al. Bla g 6:A troponin C allergen from Blattella germanica with IgE binding calcium dependence. J Allergy Clin Immunol. 2006;117(6):1389-95. 
50. Jeong $K Y$, Kim $C R$, Un S, Yi MH, Lee IY, Park JW, et al. Allergenicity of recombinant troponin $C$ from Tyrophagus putrescentiae. Int Arch Allergy Immunol. 2010;151(3):207-13.

51. Yang Y, Chen Z-W, Hurlburt BK, Li G-L, Zhang Y-X, Fei D-X, et al. Identification of triosephosphate isomerase as a novel allergen in Octopus fangsiao. Mol Immunol. 2017;85:35-46.

52. Chuang JG, Su SN, Chiang BL, Lee HJ, Chow LP. Proteome mining for novel lgE-binding proteins from the German cockroach (Blattella germanica) and allergen profiling of patients. Proteomics. 2010;10(21):3854-67.

53. Piboonpocanun S, Jirapongsananuruk O, Tipayanon $T$, Boonchoo S, Goodman RE. Identification of hemocyanin as a novel non-cross-reactive allergen from the giant freshwater shrimp Macrobrachium rosenbergii. Mol Nutr Food Res. 2011;55(10):1492-8.

54. Khanaruksombat S, Srisomsap C, Chokchaichamnankit $D$, Punyarit $P$, Phiriyangkul P. Identification of a novel allergen from muscle and various organs in banana shrimp (Fenneropenaeus merguiensis). Ann Allergy Asthma Immunol. 2014;113(3):301-6.

55. Zhang Y, Zhu L, Li S, Zhang J, She T, Yan J, et al. Identification of the major allergenic epitopes of Eriocheir sinensis roe hemocyanin: A novel tool for food allergy diagnoses. Mol Immunol. 2016;74:125-32.

56. Khurana T, Collison M, Chew FT, Slater JE. Blag 3: A novel allergen of German cockroach identified using cockroachspecific avian single-chain variable fragment antibody. Ann Allergy Asthma Immunol. 2014;112(2):140-5.

57. Abdel Rahman AM, Kamath SD, Lopata AL, Robinson JJ, Helleur RJ. Biomolecular characterization of allergenic proteins in snow crab (Chionoecetes opilio) and de novo sequencing of the second allergen arginine kinase using tandem mass spectrometry. J Proteomics. 2011;74(2):231-41.

58. Pérez-Pérez J, Fernández-Caldas E, Marañón F, Sastre J, Bernal $\mathrm{ML}$, Rodríguez J, et al. Molecular cloning of paramyosin, a new allergen of Anisakis simplex. Int Arch Allergy Immunol. 2000;123(2):120-9.

59. Guilloux L, Vuitton DA, Delbourg M, Lagier A, Adessi B, Marchand $C R$, et al. Cross-reactivity between terrestrial snails (Helix species) and house- dust mite (Dermatophagoides pteronyssinus). II. In vitro study. Allergy Eur J Allergy Clin Immunol. 1998;53(2):151-8.

60. Shanti KN, Martin BM, Nagpal S, Metcalfe DD, Rao PV. Identification of tropomyosin as the major shrimp allergen and characterization of its IgE-binding epitopes. J Immunol. 1993; 151(10):5354-63.

61. Ayuso R, Reese G, Leong-Kee S, Plante M, Lehrer SB. Molecular basis of arthropod cross-reactivity: Ige-binding crossreactive epitopes of shrimp, house dust mite and cockroach tropomyosins. Int Arch Allergy Immunol. 2002;129(1):38-48.

62. Ayuso R, Sánchez-Garcia S, Pascal M, Lin J, Grishina G, Fu Z, et al. Is epitope recognition of shrimp allergens useful to predict clinical reactivity? Clin Exp Allergy. 2012;42(2):293-304.

63. Ayuso R, Lehrer SB, Reese G. Identification of continuous, allergenic regions of the major shrimp allergen Pen a 1 (tropomyosin). Int Arch Allergy Immunol. 2002;127(1):27-37.

64. Yi FC, Cheong N, Shek PCL, Wang DY, Chua KY, Lee BW. Identification of shared and unique immunoglobulin $E$ epitopes of the highly conserved tropomyosins in Blomia tropicalis and Dermatophagoides pteronyssinus. Clin Exp Allergy. 2002;32(8):1203-10.

65. Wong L, Huang CH, Lee BW. Shellfish and House Dust Mite Allergies: Is the Link Tropomyosin? Allergy Asthma Immunol Res. 2016;8(2):101-6.

66. Wang J, Calatroni A, Visness CM, Sampson HA. Correlation of specific lgE to shrimp with cockroach and dust mite exposure and sensitization in an inner-city population. J Allergy Clin Immunol. 2011;128(4):834-7.

67. Yang Z, Zhao J, Wei N, Feng M, Xian M, Shi X, et al. Cockroach is a major cross-reactive allergen source in shrimp-sensitized rural children in southern China. Allergy Eur J Allergy Clin Immunol. 2018;73(3):585-92.

68. Fernandes J, Reshef A, Patton L, Ayuso R, Reese G, Lehrer SB. Immunoglobulin $\mathrm{E}$ antibody reactivity to the major shrimp allergen, tropomyosin, in unexposed Orthodox Jews. Clin Exp Allergy. 2003;33(7):956-61.

69. Yang Y, Liu GY, Yang H, Hu MJ, Cao MJ, Su WJ, et al. Crystal structure determination of Scylla paramamosain arginine kinase, an allergen that may cause cross-reactivity among invertebrates. Food Chem. 2019;271:597-605.

70. Kamath SD, Johnston EB, lyer S, Schaeffer PM, Koplin J, Allen $\mathrm{K}$, et al. IgE reactivity to shrimp allergens in infants and their cross-reactivity to house dust mite. Pediatr Allergy Immunol.2017;28(7):703-7.

71. Vidal C, Bartolomé B, Rodríguez V, Armisén $M$, Linneberg $A$, González-Quintela A. Sensitization pattern of crustaceanallergic individuals can indicate allergy to molluscs. Allergy Eur J Allergy Clin Immunol. 2015;70(11):1493-6.

72. van Ree R, Antonicelli L, Akkerdaas JH, Garritani MS, Aalberse RC, Bonifazi F. Possible induction of food allergy during mite immunotherapy. Allergy. 1996;51(2):108-13.

73. Cortellini G, Spadolini I, Santucci A, Cova V, Conti C, Corvetta $A$, et al. Improvement of shrimp allergy after sublingual immunotherapy for house dust mites: a case report. Eur Ann Allergy Clin Immunol. 2011;43(5):162-4.

74. Pevec B, Pevec MR, Markovic AS, Batista I. House dust mite subcutaneous immunotherapy does not induce new sensitization to tropomyosin: does it do the opposite? J Investig Allergol Clin Immunol. 2014;24(1):29-34.

75. Asero R. Lack of de novo sensitization to tropomyosin in a group of mite-allergic patients treated by house dust mite-specific immunotherapy. Int Arch Allergy Immunol. 2005;137(1):62-5.

76. Rossi RE, Monasterolo G, Incorvaia $C$, Moingeon P, Frati $F$, Passalacqua $\mathrm{G}$, et al. Lack of neo-sensitization to Pen a 1 in patients treated with mite sublingual immunotherapy. Clin Mol Allergy. 2010;8:4.

77. Huffaker MF, McGhee SA. Four cases of delayed onset systemic reaction to shellfish. J Allergy Clin Immunol Pract. 2018;6(2):656-7.

78. Lopata AL, Zinn C, Potter PC. Characteristics of hypersensitivity reactions and identification of a unique $49 \mathrm{kd}$ lgE-binding protein (Hal-m-1) in abalone (Haliotis midae). J Allergy Clin Immunol. 1997;100(5):642-8.

79. Villacis J, Rice TR, Bucci LR, El-Dahr JM, Wild L, DeMerell D, et al. Do shrimp-allergic individuals tolerate shrimp-derived glucosamine? Clin Exp Allergy. 2006;36(11):1457-61.

80. Turner $\mathrm{P}, \mathrm{Ng} \mathrm{I}$, Kemp A, Campbell D. Seafood allergy in children: A descriptive study. Ann Allergy, Asthma Immunol. 2011;106(6):494-501. 
81. Wu AY, Williams GA. Clinical characteristics and pattern of skin test reactivities in shellfish allergy patients in Hong Kong. Allergy Asthma Proc. 2004;25(4):237-42.

82. Jirapongsananuruk $O$, Sripramong $C$, Pacharn $P$, Udompunturak S, Chinratanapisit S, Piboonpocanun S, et al. Specific allergy to Penaeus monodon (seawater shrimp) or Macrobrachium rosenbergii (freshwater shrimp) in shrimp-allergic children. Clin Exp Allergy. 2008;38(6):1038-47.

83. Baynova K, Leguísamo S, Bartolomé B, Prados M. Occupational allergic contact urticaria caused by the crustaceans Palaemon serratus and Procambarus clarkii. Contact Dermatitis.2015;73(1):53-4.

84. Yamaguchi J, Inomata N, Hirokado M, Shimakura K, Shiomi K, Ikezawa Z. [A case of occupational contact urticaria and oral allergy syndrome due to seafood]. Arerugi. 2007;56(1):49-53.

85. Kalogeromitros D, Makris M, Gregoriou S, Chliva C, Katoulis A, Papaioannou $D$, et al. IgE-mediated sensitization in seafood processing workers. Allergy Asthma Proc. 2006;27(4):399403.

86. Kamath SD, Thomassen MR, Saptarshi SR, Nguyen HMX, Aasmoe L, Bang BE, et al. Molecular and immunological approaches in quantifying the air-borne food allergen tropomyosin in crab processing facilities. Int J Hyg Environ Health. 2014;217(7):740-50.

87. Malo JL, Cartier A. Occupational reactions in the seafood industry. Clin Rev Allergy. 1993;11(2):223-40.

88. Jeebhay MF, Lopata AL. Occupational Allergies in SeafoodProcessing Workers. Adv Food Nutr Res. 2012;66:47-73.

89. Muñoz-Cano R, Pascal M, Araujo G, Goikoetxea MJ, Valero AL, Picado C, et al. Mechanisms, Cofactors, and Augmenting Factors Involved in Anaphylaxis. Front Immunol. 2017;8:1193.

90. Versluis A, Van Os-Medendorp H, Kruizinga AG, Marty Blom W, Houben GF, Knulst AC. Cofactors in allergic reactions to food: Physical exercise and alcohol are the most important. Immun Inflamm Dis. 2016;4(4):392-400.

91. Pascal M, Muñoz-Cano R, Milà J, Sanz ML, Diaz-Perales A, Sánchez-López J, et al. Nonsteroidal anti-inflammatory drugs enhance IgE-mediated activation of human basophils in patients with food anaphylaxis dependent on and independent of nonsteroidal anti-inflammatory drugs. Clin Exp Allergy. 2016;46(8):1111-9.

92. Dohi M, Suko M, Sugiyama H, Yamashita N, Tadokoro K, Juji F, et al. Food-dependent, exercise-induced anaphylaxis: A study on 11 Japanese cases. J Allergy Clin Immunol. 1991;87:34-40.

93. Tokunaga $H$, Kokubu $F$, Okamoto $M$, Miyamoto $M$, Hanyuuda M, Adachi M. [A case of food-dependent exercise-induced anaphylaxis induced by shrimp]. Arerugi. 1995;44(11):1297-304.

94. Kimura H, Inami M, Hamaguchi Y, Takehara K, Akimoto S, Yokooji T, et al. Food-dependent exercise-induced anaphylaxis due to shrimp associated with $43 \mathrm{kDa}$, a new antigen. J Dermatol. 2018;45(3):366-7.

95. Niggemann B, Beyer K. Factors augmenting allergic reactions. Allergy Eur J Allergy Clin Immunol. 2014;69(12):1582-7.

96. Asero R, Scala E, Villalta D, Pravettoni V, Arena A, Billeri $L$, et al. Shrimp allergy: Analysis of commercially available extracts for in vivo diagnosis. J Investig Allergol Clin Immunol. 2017:27(3):175-82.

97. Carnés J, Ferrer Á, Huertas ÁJ, Andreu C, Larramendi $\mathrm{CH}_{\text {, }}$ Fernández-Caldas $\mathrm{E}$. The use of raw or boiled crustacean extracts for the diagnosis of seafood allergic individuals. Ann Allergy Asthma Immunol. 2007;98(4):349-54.

98. Samson KTR, Chen FH, Miura K, Odajima Y, likura Y, Rivas MN, et al. IgE binding to raw and boiled shrimp proteins in atopic and nonatopic patients with adverse reactions to shrimp. Int Arch Allergy Immunol. 2004;133(3):225-32.

99. Rosen JP, Selcow JE, Mendelson LM, Grodofsky MP, Factor JM, Sampson HA. Skin testing with natural foods in patients suspected of having food allergies: is it a necessity? J Allergy Clin Immunol. 1994;93(6):1068-70.

100. Ballmer-Weber BK, Fernandez-Rivas M, Beyer K, Defernez M, Sperrin M, Mackie AR, et al. How much is too much? Threshold dose distributions for 5 food allergens. J Allergy Clin Immunol. 2015;135(4):964-71.

101. Bindslev-Jensen C, Ballmer-Welser BK, Bengtsson U, Blanco C, Ebner C, Hourihane J, et al. Standardization of food challenges in patients with immediate reactions to foods Position paper from the European Academy of Allergology and Clinical Immunology. Allergy Eur J Allergy Clin Immunol. 2004;59(7):690-7.

102. Nordlee JA, Remington BC, Ballmer-Weber BK, Lehrer SB, Baumert JL, Taylor SL. Threshold Dose for Shrimp: A Risk Characterization Based On Objective Reactions in Clinical Studies. J Allergy Clin Immunol. 2013;131(2):AB88.

103. Sastre J. Molecular diagnosis in allergy. Clin Exp Allergy. 2010;40(10):1442-60.

104. Lopata AL, Kleine-Tebbe J, Kamath SD. Allergens and molecular diagnostics of shellfish allergy. Allergo J Int. 2016;25(7):2108.

105. Lin J, Sampson HA. The role of immunoglobulin E-binding epitopes in the characterization of food allergy. Curr Opin Allergy Clin Immunol. 2009;9(4):357-63.

106. Flinterman $A E$, Knol EF, Lencer DA, Bardina L, den Hartog Jager CF, Lin J, et al. Peanut epitopes for IgE and IgG4 in peanutsensitized children in relation to severity of peanut allergy. J Allergy Clin Immunol. 2008;121(3):737-43.

107. Shreffler WG, Beyer K, Chu THT, Burks AW, Sampson HA. Microarray immunoassay: Association of clinical history, in vitro $\lg E$ function, and heterogeneity of allergenic peanut epitopes. J Allergy Clin Immunol. 2004;113(4):776-82.

108. Beyer K, Jarvinen KM, Bardina L, Mishoe M, Turjanmaa K, Niggemann $B$, et al. IgE-binding peptides coupled to a commercial matrix as a diagnostic instrument for persistent cow's milk allergy. J Allergy Clin Immunol. 2005;116(3):704-5.

109. Matsumoto N, Okochi M, Matsushima M, Kato R, Takase T, Yoshida $Y$, et al. Peptide array-based analysis of the specific $\lg \mathrm{E}$ and $\lg \mathrm{G} 4$ in cow's milk allergens and its use in allergy evaluation. Peptides. 2009;30(10):1840-7.

110. Järvinen KM, Beyer K, Vila L, Bardina L, Mishoe M, Sampson $H A$. Specificity of $\lg E$ antibodies to sequential epitopes of hen's egg ovomucoid as a marker for persistence of egg allergy. Allergy Eur J Allergy Clin Immunol. 2007;62(7):75865.

111. Yang AC, Arruda LK, Santos ABR, Barbosa MCR, Chapman MD, Galvão CES, et al. Measurement of IgE antibodies to shrimp tropomyosin is superior to skin prick testing with commercial extract and measurement of $\mathrm{lg} \mathrm{E}$ to shrimp for predicting clinically relevant allergic reactions after shrimp ingestion. J Allergy Clin Immunol. 2010;125(4):872-8. 
112. Khor SS, Morino R, Nakazono K, Kamitsuji S, Akita M, Kawajiri $M$, et al. Genome-wide association study of selfreported food reactions in Japanese identifies shrimp and peach specific loci in the HLA-DR/DQ gene region. Sci Rep. 2018;8(1):1069.

113. Muraro A, Werfel T, Hoffmann-Sommergruber $K$, Roberts $G$ Beyer K, Bindslev-Jensen C, et al. EAACl Food Allergy and Anaphylaxis Guidelines: Diagnosis and management of food allergy. Allergy Eur J Allergy Clin Immunol. 2014;69(8):100825.

114. Feuille E, Nowak-Wegrzyn A. Allergen-specific immunotherapies for food allergy. Allergy Asthma Immunol Res. 2018;10(3):189206.

115. Zhernov $Y$, Curin $M$, Khaitov M, Karaulov A, Valenta R. Recombinant allergens for immunotherapy: State of the art. Curr Opin Allergy Clin Immunol. 2019;19(4):402-14.

116. Wai CYY, Leung NYH, Chu KH, Leung PSC, Leung ASY, Wong GWK, et al. Overcoming shellfish allergy: How far have we come? Int J Mol Sci. 2020;21(6):2234.
117. Sporik R, Hill DJ, Hosking CS. Specificity of allergen skin testing in predicting positive open food challenges to milk, egg and peanut in children. Clin Exp Allergy. 2000;30(11):1541-6.

- Manuscript received April 24, 2020; accepted for publication May 28, 2020.

\section{Antonio Valero}

Chief Allergy Section

Hospital Clínic de Barcelona

Servei de Neumologia i Al·lèrgia. Institut Clinic Respiratori Planta 2, entre escalera 6 y 8

Hospital Clínic

C/Villarroel, 170

08036 Barcelona, Spain

E-mail: valero@clinic.cat 